\title{
The Relationship of Professional Ability and Management System Construction Under Mediation of Administrative Expert Role Cognition
}

\author{
Shun Hsien-Yu \\ GuangDong University of Petrochemical Technology
}

This research explored the relationship among human resource practitioner professional ability, administrative expert role cognition and the degree of human resource management system construction. The paper is based on a questionnaire survey. Data collected from the foreign investment enterprise list in Shanghai city, China. Eight hundred questionnaires were sent out, 223 valid questionnaires were returned (27.88\%). The results show that there is a significant influence between the: (1) Professional ability of human resource practitioners and the degree of human resource management system construction and (2) administrative expert role cognition of human resource practitioners and human resource management system construction and also that (3) administrative expert role cognition has a partial mediating effect between professional ability and the degree of human resource management system construction. The originality and value of this study is one of very few studies which have investigated that administrative expert role has the mediating effect between the human resource practitioners professional ability and human resource management system construction.

Keywords: administrative expert, hierarchy, linear regression, human resource management system, mediating effect, professional ability

\section{INTRODUCTION}

To succeed in a globalized economy, an organization must invest in human resources enhance skills and competences. Some studies have pointed out that human resource management systems play an important role in the relationship between organizations and employees, and the degree of system construction will affect the organizational performance. (Lin et al., 2019). Jamali and Sargirani (2021) argued the human resource department its essential goal has two in organization: management of the people (productivity) and objectives of organization (corporate profits). To effectively face new challenges, human resource departments must focus on how to add department value, how to organize, improve their effectiveness, and develop new capabilities. Shun (2018) argued due to the limited resources of the organization, human resources departments (including other departments) are required to achieve more output with less resources. Only good at process improvement can achieve the goal of efficiency improvement. Human resource professionals who play the role of administrative experts can eliminate unnecessary costs, improve efficiency, and continuously find better ways to do things. Ward (2015) asserted the human resource administrative experts also like advisors are the internal consultants of an organization. Their jobs are to offer their expertise in human resource services (e.g. training and selection of employees) to the line managers of the firm. However the line managers are still responsible for the decision which 
trainings will be offered and to whom. Therefore the administrative expert can be seen as consultants i.e. allowing other employees to use your knowledge, with the main task to advise the line managers in doing their jobs.

Lemmergaard's (2009) research aimed to investigate the HR role performance of a case organization. This empirical study showed that the human resource executive can operate as administrative expert and change agent simultaneously. Wright, Gardner and Moynihan (2002) studied on the relationship between HR activities and organizational performance and profitability, and found that HR management activities (e.g., recruitment and selection, training, performance, compensation system, employee participation) and organizational commitment are related to the measurement of operational performance, operating costs, and pre-tax revenue.

\section{THEORY AND HYPOTHESES}

\section{Human Resource Practitioner Professional Ability}

To achieve an organizational purpose, one of the roles of human resource management is to assist the organization to develop management systems by coordinating and communicating with internal personnel (Hall and Goodale,1986; Schuler, 1987). Constructing organizational policy and system processes is the basic work of a typical human resources department. Human resource professionals must design and implement effective human resource systems and processes, including recruitment management, training development, salary management, performance management and relevant personnel administration systems to ensure the coherency in management organization. Ulrich (1995) proposed that the structure of human resource professional function should include three main aspects: enterprise management knowledge, human resource professional functions and change management. Huselid, Jackson and Schuler (1997) proposed human resource professional goals may be associated with: human resource strategy planning, leadership, resource control, external Internet use management, enhancing human resource service quality, and risk-taking.

Ruona and Gibson (2004) suggested that since the early 1990s, the strategic role of human resources has gradually increased. Human resource personnel must cooperate with organizational strategies to design a human resources management system that can enhance organizational competitiveness and improve the value of human resource functions. Yu et al. (2012) designed an employee performance evaluation system according to organizational strategy, proposed measures to balance work and physical and mental stated of employees, and formulated a good reward system to attract outstanding colleagues to retain in an organization. Parul and Shabana (2019) argued that the human resource core functions including: recruiting the right people to the right work, maintaining the safe environment, employer and employee relations, pay and benefits, training and development. To adapt to organizational change and implement it smoothly, a human resources department needs to construct a management system to fit the development of that particular organization. Therefore, the professional ability of human resource practitioners should influence human resource management system construction. Therefore, the first hypothesis of this study is:

\section{H1: Higher professional ability of HR practitioner has a positive impact on the human resource system} construction.

\section{Administrative Expert Role}

Human resource administrative expert concept is originally from a book written by David Ulrich in 1997: "Human Resource Champions: the next agenda for adding value and delivering results". In this book, human resource business partner concept is initiated for the first time, which improves the positioning of human resource function from administrative to the organizational business partner. Ulrich (1997) proposed human resource business partner role included: strategic partner, change agent, administrative expertise and employee champion. It's greatly promotes the development of global human resource management and also a revolutionary concept promotion of human resource management. Above these four roles, administrative expert role is an important role of business partner. Sun (2019) asserted the human resource administrative 
expert also played an operation manager role because the business development was affected by the operation enterprise. The performance of operation manager is to promote the corporate rules, business procedures, listen the employee's opinions and update the human resource projects sync with corporate goal.

Shun (2018) argued the human resource professionals improve their efficiency in two ways: first, to ensure the efficiency of human resource processes, such as the administrative process reengineering. The second way for HR department to improve the overall operation efficiency of the company is to recruit, train and reward those who have the abilities to improve productivity, reduce costs and waste, and improve work efficiency. By improving administrative efficiency, human resource professionals can strength the role of administrative experts. Yusliza (2012) argued that the administrative expert concerned more with the process efficiency of internal organization. The role play needs human resource professionals design the delivery human resource process and system for staffing, training, appraisal, reward, promotion and other management flow of employees through the organization.

Human resource unit adopts an administrative expert role, it ensures that human resource function processes such as staffing, training, and data management are carried out efficiently and effectively (Lemmergaard, 2009; Ulrich \& Brockbank, 2005). Administrative expert role is to create competitive advantage and increasing operational efficiency through the process and management system design reasonable. From the literature review, it was noted that the administrative expert role cognition may depend on degree of individual professional abilities. The professional abilities will guide the effective design of human resource management system and process. Whether the construction of a human resource management system is robust also is a function of goal setting and performance presentation of the department unit. So, hypothesis $2 \mathrm{a}$ and hypothesis $2 \mathrm{~b}$ of this study are as follow:

H2a: Higher professional ability of an HR practitioner has a positive impact on administrative expert role cognition.

H2b: Higher administrative expert role cognition of an HR practitioner has a positive impact on the human resource system construction.

\section{Human Resource Management System Construction}

Zhou(2008) believed that human resource management systems should use modern scientific methods to carry out reasonable training, organization, and allocation of human resources, combined with certain material resources. Through the design of the system, people's thoughts and psychological behaviors should be properly induced, controlled, and coordinated to achieve their potential to achieve organizational goals. Liu and Shi (2005) pointed out human resource management practice refers to numerous policies and systems that affect employees' behaviors, attitudes and performance. Hsu et al. (2014) made an important classification according to five dimensions of human resource management: (1) recruitment and selection, (2) training and development, (3) performance evaluation and management, (4) salary and welfare, and (5) employee relation.

If a business does not have a complete human resource management system, daily operations and procedures cannot be carried out smoothly. If the human resource management system construction is good, it will attract talent effectively since the job seekers are often attentive to such issues. (Lievens et al., 2001). Peng (2012) suggested the problems of the human resource management systems of small businesses cannot be well established complete because they are limited cost scales to establish and integrate the system. Wang (2011) pointed out that organizations should establish a human resource evaluation system first, attracting talent then managing that talent.

Suzanne (2010) highlighted the advantages of talent competition for large enterprises are obvious because they establish the best human resource management systems. From the above literature discussion, we documented the importance of human resource management system construction to organizational performance and personnel management. The degree of human resource management system construction also depends on the work performance of human resource departments. The performance, in turn, depends 
on the work ability and motivation willingness of the employees. If the professional ability is good yet achievement motivation is not, the final job performance may not achieve expected goals. Therefore, hypothesis 3 is :

H3: Administrative expert role has a mediating effect between the HR practitioner professional ability and the degree of human resource system construction.

The purpose of this research is to discuss the relationship between the professional ability of human resource practitioners and the construction of a human resource management system, and examine the achievement motivation of human resource practitioners as a mediating variable. The research framework is shown in Figure 1.

FIGURE 1

RESEARCH FRAMEWORK

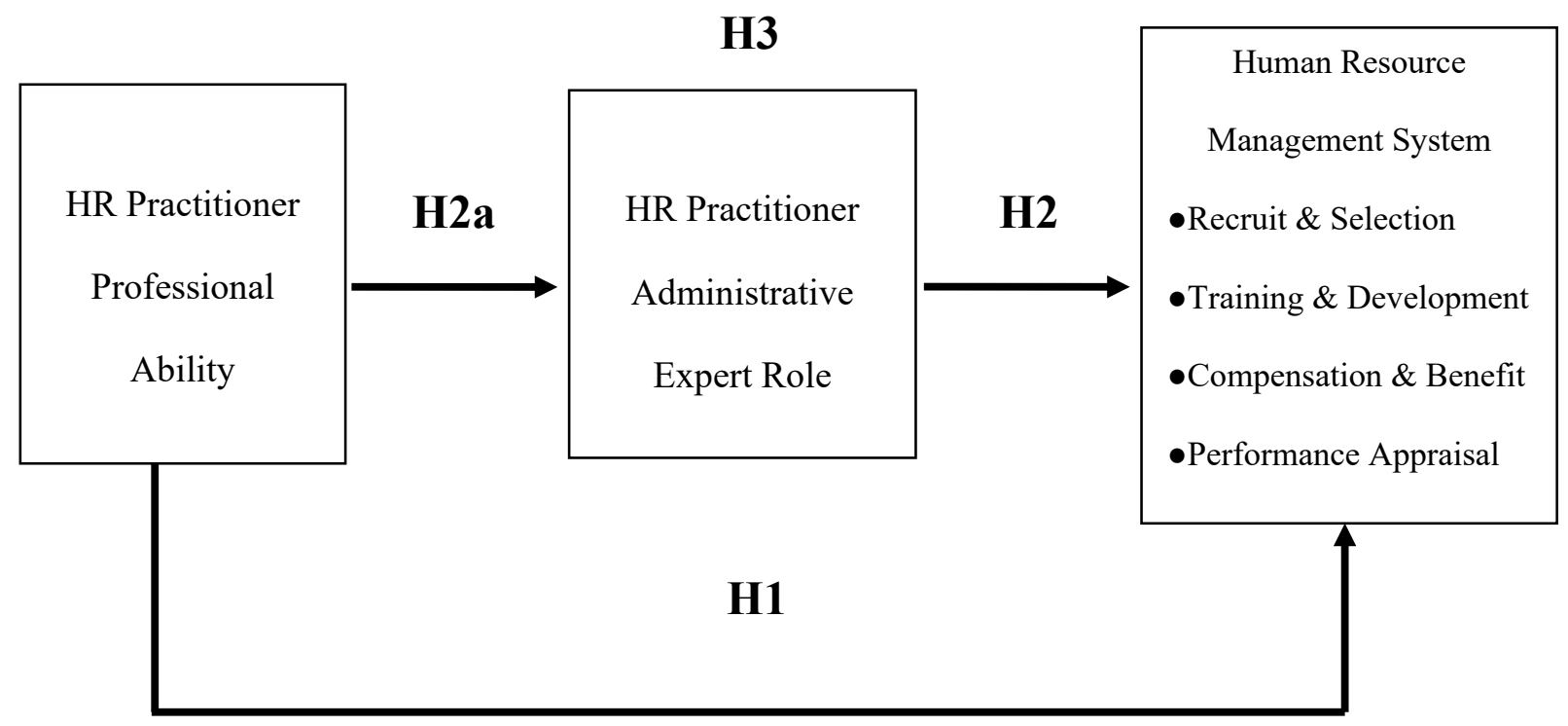

\section{Methodology}

Due to the requirement of data analysis, samples came from the foreign investment enterprise lists in Shanghai City, China. Respondents were all work in HR related professional fields. The collection period was from July 2019 to the end of January 2020. Eight hundred questionnaires were sent out, 231 of which were returned $(28.86 \%)$, and eight invalid questionnaires were eliminated, leaving 223 that were valid $(27.88 \%)$.

\section{Measures}

The questionnaire design included three parts. (1) The professional ability questionnaire refers to the questions used by Huselid, Jackson \& Schuler (1997). In this study, five of the questions were used to evaluate professional abilities, including in areas such as human resource expertise, external network resources, and service quality. Topics were measured by a 6-point Likert scale with 『6』 represent "agrees very much" and "1" represent "disagree very much". The higher the score, the higher degree of the professional ability of the human resource practitioners. (2) The human resource administrative expert role questionnaire refers to the questions used by Ulrich (1997). In this study, five of the questions were used to evaluate administrative expert role cognition. Topics were measured by a 6-point Likert scale with 『6』 represent "agrees very much" and "1" represent "disagree very much". The higher the score, the higher 
degree of the administrative expert role cognition. (3)The human resource management system construction questionnaire design based on Hsu et al. (2014), including recruitment and selection(three questions), training and development (three questions), compensation and benefits(three questions), performance appraisal(four questions), and employee relation(five).

\section{Results and Discussion}

Respondents' Demographic Profiles

Demographic data include: gender, age, education level, organization position, organizational scale, and industry. The basic information of the sample collected from the questionnaire is shown in Table 1.

TABLE 1

SAMPLES STRUCTURE ANALYSIS

\begin{tabular}{|c|c|c|c|}
\hline Item & Characteristic & Samples & Percentage \\
\hline \multirow{2}{*}{ Sex } & Male & 64 & $28.7 \%$ \\
\hline & Female & 159 & $71.3 \%$ \\
\hline \multirow{4}{*}{ Age } & Under 30 & 32 & $14.3 \%$ \\
\hline & $31 \sim 35$ & 89 & $39.9 \%$ \\
\hline & $36 \sim 40$ & 63 & $28.3 \%$ \\
\hline & 40 Above & 39 & $17.5 \%$ \\
\hline \multirow{4}{*}{ Education } & Senior High School & 5 & $2.2 \%$ \\
\hline & College & 17 & $7.6 \%$ \\
\hline & University & 152 & $68.2 \%$ \\
\hline & Master Above & 49 & $22.0 \%$ \\
\hline \multirow{5}{*}{ Position } & Staff & 14 & $6.3 \%$ \\
\hline & Supervisor & 52 & $23.3 \%$ \\
\hline & Manager & 95 & $42.6 \%$ \\
\hline & Director & 46 & $20.6 \%$ \\
\hline & VP Above & 16 & $7.2 \%$ \\
\hline \multirow{5}{*}{ Org. Scale } & Under 50 & 17 & 7.6 \\
\hline & $51 \sim 100$ & 65 & $29.1 \%$ \\
\hline & $101 \sim 300$ & 87 & $39.0 \%$ \\
\hline & $301 \sim 500$ & 24 & $10.8 \%$ \\
\hline & 501 Above & 30 & $13.5 \%$ \\
\hline \multirow{3}{*}{ Industry } & Whole sell Service & 65 & $29.1 \%$ \\
\hline & Professional Service & 112 & $50.2 \%$ \\
\hline & Manufacture & 46 & $20.6 \%$ \\
\hline
\end{tabular}

\section{Reliability and Validity Analysis}

Reliability analysis is using internal consistency (Cronbach's Alpha) to measure the relationship of all included items. After internal consistency analysis, each item's reliability value was $\geqq 0.7$, suggesting the internal consistency reliability is acceptable (Nunnally, 1978). Human resources professional ability Cronbach's $\alpha$ value was 0.771 , administrative expert was 0.786 , the human resources system formulation is $\geqq 0.7$. The results are shown in Table 2 . 
TABLE 2

RELIABILITY ANALYSIS OF QUESTIONNAIRE

\begin{tabular}{cccc}
\hline Variable Name & Dimension & Number & Cronbach's $\alpha$ \\
\hline Professional Ability & Overall questions & 5 & 0.771 \\
Administrative Expert & Overall questions & 5 & 0.786 \\
& Recruitment \& Selection & 3 & 0.782 \\
& Training \& Development & 3 & 0.763 \\
Human Resource & Compensation \& Benefits & 3 & 0.782 \\
Management System Items & Performance Management & 4 & 0.767 \\
& Employee Relation & 5 & 0.754 \\
\hline
\end{tabular}

We used Bartlett's test of sphericity to determine the multivariate normality of the variables. The Kaiser-Meyer-Olkin (K-M-O) test evaluates sampling adequacy regarding whether the distribution of values is sufficient for conducting factor analysis (George and Mallery, 2016). According to Tabachnick and Fidell (2007), data is factorable when the KMO value is above a minimum acceptable level of 0.60 . In this research, the KMO test values were all above 0.6, which indicated sampling adequacy and the distribution was appropriate to conduct factor analysis. Explore factor analysis was used to measure the structural validity of the scale, and the factor with an Eigen-value above one was retained. Principle component analysis, using the varimax method for the orthogonal rotation, which is then used to adjust the factor loading. In terms of professional ability, there were originally five questions, but we deleted questions 1 and 5 because the factor loading was not above 0.5 ; after deletion, the factor loading was above 0.5 . The $\alpha$ value after deleting the questions was 0.722 , indicating the internal consistency was maintained and results are shown in Table 3.

TABLE 3

DIMENSION、EIGEN VALUE AND VARIANCE EXPLANATION

\begin{tabular}{ccc}
\hline Dimension & Question & Factor \\
\hline Professional & HRPRO2 & 0.678 \\
Ability & HRPRO3 & 0.649 \\
Eigen Value & HRPRO4 & 0.624 \\
\hline Variance Explanation (\%) & & 1.951 \\
& & $61.032 \%$ \\
\hline
\end{tabular}

KMO Sampling Adequacy Testing Value : 0.682

Bartlett Test Sphericity : Chi-Suqare $=137.959$, d.f. $=3$ Sig. $=0.000$

Factor Extraction : Principal Component Analysis, PCA.

There were originally five questions about administrative expert, but we deleted questions 4 and 5 because the factor loading did not meet the requirement to be above 0.5 . After deletion, the factor loading value reached the 0.5 requirement. The reliability $\alpha$ value after deleting the questions was 0.767 , indicating the internal consistency was maintained after deleting the question. The results are shown in Table 4. 
TABLE 4

DIMENSION、EIGEN VALUE AND VARIANCE EXPLANATION

\begin{tabular}{ccc}
\hline Dimension & Question & Factor \\
\hline Administrative & ADMEXPTO1 & 0.728 \\
Expert & ADMEXPTO2 & 0.695 \\
Eigen Value & ADMEXPTO3 & 0.662 \\
Variance Explanation (\%) & & 2.085 \\
\hline
\end{tabular}

KMO Sampling Adequacy Testing Value : 0.698

Bartlett Test Sphericity : Chi-Suqare $=184.614$, d.f. $=3$ Sig. $=0.000$

Factor Extraction : Principal Component Analysis, PCA.

The human resource management systems, there were three questions about compensation and benefits, but we deleted question 1 because the factor loading did not meet the 0.5 requirement; there were four questions about performance appraisal, and question 4 was deleted; employee relationship, question 1 was deleted. After deletion, the other factors loading value reached the 0.5 requirement. The $\alpha$ value after deleting the questions was $\geqq 0.7$, which means that good internal consistency was maintained. The results are shown in Table 5.

TABLE 5

DIMENSION、EIGEN VALUE AND VARIANCE EXPLANATION

\begin{tabular}{|c|c|c|c|c|c|c|}
\hline Dimension & Question & Factor 1 & Factor 2 & Factor 3 & Factor 4 & Factor 5 \\
\hline \multirow{3}{*}{$\begin{array}{l}\text { Recruit \& } \\
\text { Selection }\end{array}$} & $\mathrm{R} \& \mathrm{~S} 1$ & 0.671 & & & & \\
\hline & $\mathrm{R} \& \mathrm{~S} 2$ & 0.731 & & & & \\
\hline & $\mathrm{R} \& \mathrm{~S} 3$ & 0.718 & & & & \\
\hline \multirow{3}{*}{$\begin{array}{c}\text { Training \& } \\
\text { Development }\end{array}$} & T\&D1 & & 0.612 & & & \\
\hline & T\&D2 & & 0.723 & & & \\
\hline & T\&D3 & & 0.807 & & & \\
\hline \multirow{2}{*}{$\begin{array}{l}\text { Compensation } \\
\text { \& Benefits }\end{array}$} & C\&B1 & & & 0.661 & & \\
\hline & C\&B2 & & & 0.832 & & \\
\hline \multirow{3}{*}{$\begin{array}{l}\text { Performance } \\
\text { Appraisal }\end{array}$} & PA1 & & & & 0.643 & \\
\hline & PA2 & & & & 0.777 & \\
\hline & PA3 & & & & 0.579 & \\
\hline \multirow{4}{*}{$\begin{array}{l}\text { Employee } \\
\text { Relation }\end{array}$} & ER2 & & & & & 0.621 \\
\hline & ER3 & & & & & 0.692 \\
\hline & ER4 & & & & & 0.683 \\
\hline & ER5 & & & & & 0.738 \\
\hline \multicolumn{2}{|c|}{ Eigen Value } & 2.137 & 2.090 & 1.661 & 1.560 & 1.393 \\
\hline \multicolumn{2}{|c|}{ Variance Explanation (\%) } & 14.24 & 13.93 & 11.07 & 10.39 & 9.28 \\
\hline \multicolumn{2}{|c|}{$\begin{array}{l}\text { Accumulate Variance } \\
\text { Explanation }(\%)\end{array}$} & 14.24 & 27.63 & 38.70 & 49.09 & 58.37 \\
\hline
\end{tabular}

KMO Sampling Adequacy Testing Value : 0.747

Bartlett Test Sphericity : Chi-Suqare $=611.56$, d.f. $=105$ Sig. $=0.000$

Factor Extraction : Principal Component Analysis, PCA.

Pearson Correlation Analysis

Pearson correlation analysis was employed and Table 6 and Table 7 show the results. 
TABLE 6

VARIABLES PERSON CORRELATION ANALYSIS (HRM SYSTEM CONSTRUCTION)

\begin{tabular}{cccccc}
\hline VAR & Mean & STD & $\begin{array}{c}\text { Professional } \\
\text { Ability }\end{array}$ & $\begin{array}{c}\text { Administrative } \\
\text { Expert }\end{array}$ & $\begin{array}{c}\text { HRM } \\
\text { System } \\
\text { Construction }\end{array}$ \\
\hline $\begin{array}{c}\text { Professional } \\
\text { Ability } \\
\begin{array}{c}\text { Administrative } \\
\text { Expert }\end{array}\end{array}$ & 4.962 & 0.488 & 1 & & \\
HRM System & 4.933 & 0.487 & $0.367 * * *$ & 1 & \\
\hline$* * *, p<0.001 ; *^{* *}, p<0.01 ; *, p<0.05 ;+, p<0.1$ & 0.377 & $0.313^{* * *}$ & $0.397 * * *$ & 1 \\
\hline
\end{tabular}

TABLE 7

VARIABLES PERSON CORRELATION ANALYSIS (HRM SYSTEM EACH ITEM)

\begin{tabular}{|c|c|c|c|c|c|c|c|c|c|}
\hline VAR & Mean & STD & PRO A. & ADM E. & $R \& S$ & $\mathrm{~T} \& \mathrm{D}$ & C\&B & P.A. & E.R. \\
\hline $\begin{array}{c}\text { PRO } \\
\text { A. }\end{array}$ & 4.962 & 0.488 & 1 & & & & & & \\
\hline $\begin{array}{c}\text { ADM } \\
\text { E. }\end{array}$ & 4.933 & 0.487 & $0.367 * * *$ & 1 & & & & & \\
\hline $\mathrm{R} \& S$ & 4.918 & 0.671 & 0.107 & $0.170^{*}$ & 1 & & & & \\
\hline $\mathrm{T} \& \mathrm{D}$ & 4.901 & 0.616 & $0.133 *$ & $0.253 * * *$ & $0.472 * * *$ & 1 & & & \\
\hline C\&B & 4.960 & 0.550 & 0.103 & $0.304 * * *$ & $0.318 * * *$ & $0.396 * *$ & 1 & & \\
\hline P.A. & 5.090 & 0.481 & $0.339 * * *$ & $0.291 * * *$ & $0.218 * *$ & $0.286^{* *}$ & $0.312 * * *$ & 1 & \\
\hline E.R. & 4.913 & 0.566 & $0.296^{* * *}$ & $0.289 * * *$ & $0.236 * *$ & $0.192 * *$ & $0.113+$ & $0.390 * * *$ & 1 \\
\hline
\end{tabular}

Note: PRO A: Professional Ability. ADM E: Administrative Expert R\&S: Recruit \& Select T\&D: Training \& Development C\&B: Compensation \& Benefit PA: Performance Appraisal. ER: Employee Relation.

$* * *, p<0.001 ; * *, p<0.01 ; *, p<0.05 ;+, p<0.1$

There was a significant positive correlation between the professional ability and the training and development system $(0.133 *)$, performance management $\left(0.339^{* * *}\right)$, and employee relationship $\left(0.296^{* * *}\right)$. There was a significant positive correlation between administrative expert and five sub-items: recruit and select system $\left(0.170^{*}\right)$, training and development system $(0.253 * * *)$, compensation and benefits system $\left(0.304^{* * *}\right)$, performance appraisal system $\left(0.291^{* * *}\right)$ and employee relation system $\left(0.289^{* * *}\right)$.

\section{Linear Hierarchy Regression Analysis}

We used linear hierarchy regression to analyze the influence of professional ability, human resource system construction and achievement motivation. Then, we will test whether there is a mediating effect of achievement motivation between human resource practitioner's professional ability and the human resource management system construction. The verification procedure will follow Baron and Kenny (1986) process to test the mediating effect. There are three necessary conditions for the mediating effect test: (1) Independent variable has a significant affects on dependent variable; (2) Independent variable has a significant affects on mediating variable; (3) Mediating variable has a significant affects on the dependent variable. If the influence of the independent variable on the dependent variable is gradually reduced after the mediator variable is added, it is called partial mediating effect; if the influence is reduced to zero, it's called complete mediating effect. The results shown as table 8 . 


\section{TABLE 8 \\ ADMINISTRATIVE EXPERT MEDIATING EFFECT BETWEEN THE PROFESSIONAL ABILITY AND HRM SYSTEM CONSTRUCTION WITH LINEAR HIERARCHY REGRESSION ANALYSIS}

\begin{tabular}{|c|c|c|c|c|c|c|c|c|}
\hline \multirow{4}{*}{ Variable Items } & \multicolumn{8}{|c|}{ Dependent Variable } \\
\hline & \multirow{2}{*}{\multicolumn{2}{|c|}{$\begin{array}{c}\begin{array}{c}\text { Administrative } \\
\text { Expert }\end{array} \\
\text { Model } 1 \\
\end{array}$}} & \multicolumn{6}{|c|}{ HRM System Construction Degree } \\
\hline & & & \multicolumn{2}{|c|}{ Model 2} & \multicolumn{2}{|c|}{ Model 3} & \multicolumn{2}{|c|}{ Model 4} \\
\hline & $\beta$ & $\mathrm{T}$ & $\beta$ & $\mathrm{T}$ & $\beta$ & $\mathrm{T}$ & $\beta$ & $\mathrm{T}$ \\
\hline $\begin{array}{c}\text { (Independent Variable) } \\
\text { Professional Ability }\end{array}$ & 0.367 & 5.868 & 0.313 & 4.896 & --- & --- & 0.193 & 2.961 \\
\hline $\begin{array}{l}\text { (Mediator Variable) } \\
\text { Administrative Expert }\end{array}$ & --- & --- & --- & --- & 0.397 & 6.424 & 0.326 & 4.993 \\
\hline $\mathrm{R}^{2}$ & \multicolumn{2}{|c|}{0.135} & \multicolumn{2}{|c|}{0.098} & \multicolumn{2}{|c|}{0.157} & \multicolumn{2}{|c|}{0.190} \\
\hline$\triangle \mathrm{R}$ & \multicolumn{2}{|c|}{0.135} & \multicolumn{2}{|c|}{0.098} & \multicolumn{2}{|c|}{0.157} & \multicolumn{2}{|c|}{0.092} \\
\hline Adj. $R^{2}$ & \multicolumn{2}{|c|}{0.131} & \multicolumn{2}{|c|}{0.094} & \multicolumn{2}{|c|}{0.154} & \multicolumn{2}{|c|}{0.182} \\
\hline F Value & \multicolumn{2}{|c|}{$34.432 * * *$} & \multicolumn{2}{|c|}{$23.967 * * *$} & \multicolumn{2}{|c|}{$41.272 * * *$} & \multicolumn{2}{|c|}{$25.745^{* *}$} \\
\hline
\end{tabular}

***, $p<0.001 ; * *, p<0.01 ; *, p<0.05 ;+, p<0.1$

Professional Ability and HRM System Construction

Table 8 shows model 2 as the professional ability of a HR practitioner and the effect of human resource management system construction, $\beta$ is $0.313^{* * *}(\mathrm{P}<0.001)$, a significant positive correlation. Thus, hypothesis 1 was supported.

Professional Ability and Administrative Expert

Table 8 shows model 1 as the professional ability of a HR practitioner and the effect of administrative expert, $\beta$ is $0.367^{* * *}(\mathrm{P}<0.001)$, a significant positive correlation. Thus, hypothesis $2 \mathrm{a}$ was supported.

\section{Administrative Expert and HRM System Construction}

As shown in Table 8, model 3 includes administrative expert as an independent variable in the regression analysis. The effect of administrative expert role on human resource management system construction, $\beta$ is $0.397 * * *(\mathrm{P}<0.001)$, reaching a significant positive correlation. Thus, hypothesis $2 \mathrm{~b}$ was supported.

\section{Mediating Effect Test}

As shown in Table 8, model 4 examined the mediating effect of administrative expert between professional ability and human resource management system construction. The results in model 4 , the professional ability (independent variable) $\beta$, is $0.193 * *(\mathrm{P}<0.01$ ), administrative expert (mediator variable) $\beta$, is $0.326 * * *(\mathrm{P}<0.001)$, which has a significant positive relationship. Compare the differentiation of model $2 \beta$ value $\left(0.313^{* * *}\right)$ and model $4 \beta$ value $\left(0.193^{* *}\right)$. After model 4 added into the administrative expert as mediator, the professional ability affect the human resource system construction is gradually reduce. It meant the administrative expert has a partial mediating effect between the professional ability and human resource system construction. Hypothesis 3 was supported. Hypothesis outcomes are shown in Table 9. 
TABLE 9

HYPOTHESIS OUTCOMES

\begin{tabular}{clc}
\hline Items & \multicolumn{1}{c}{ Hypothesis Content } & Outcomes \\
\hline Hypothesis 1 & $\begin{array}{l}\text { Higher professional ability of HR practitioner has a positive } \\
\text { impact on the human resource system construction. }\end{array}$ & Support \\
Hypothesis 2a & $\begin{array}{l}\text { Higher professional ability of an HR practitioner has a } \\
\text { positive impact on administrative expert role cognition. } \\
\text { Hypher administrative expert role cognition of HR } \\
\text { practitioner has a positive impact on the human resource } \\
\text { system construction. } \\
\text { Administrative expert role has a mediating effect between } \\
\text { the HR practitioner professional ability and the relative } \\
\text { degree of human resource system construction. }\end{array}$ & Support \\
\hline
\end{tabular}

\section{CONCLUSION}

This research explored the influence of the professional ability of HRM practitioners on human resource management system construction. The main results included: (1). the higher the professional ability of human resource management practitioners, the more positive impact on human resource system construction, (2).the higher administrative expert role cognition degree of human resource practitioners, the more positive impact on human resource system construction, and (3).administrative expert role exist a partial mediating effect between professional ability and human resource system construction.

\section{The Relationship of Professional Ability and Management System Construction}

We showed the level of professional ability of HR practitioners has a significant positive impact on human resource system construction. Organizational performance relates to human resource management system construction. In management, enterprises improve internal process and enhancing professional abilities is one way to do so. The professional abilities of human resource practitioner include professional knowledge and skill, improve the internal customer service quality, formulate management system and policy and cross departmental coordination. In human resource practices, professional abilities can enhance through the internal and external professional course training, projects implementation plan, job rotation project design, job agent project and so on. The empirical results of this study also prove the professional ability of human resources practitioners has a significant positive impact on management system construction. Therefore, the HR department manager can carry out the above mentioned ability improvement plans from the daily work arrangement to improve the ability of personnel. Even though count in the annually department budget items for professional ability improvement plan and induct the external resources shall be carried out to optimize the professional ability of human resource practitioner.

\section{The Relationship of HR Expert Role Cognition and Management System Construction}

Administrative expert role cognition refers to an internal tendency of individuals to engage in human resource practice works that they think is important or valuable, and strive to reach a high level job performance. People with high degree cognition of administrative expert role will seek solutions in their respective areas, like to set moderately difficult goals, and hope to have specific feedback to understand the quality of their work. Most high degree administrative expert cognition will have the performance-oriented tendency. Due to the role cognition belongs to the part of deep-inside personality traits, which is difficult to be changed through external training. In business practice application, we can evaluate the human resource candidates through personality test during the recruitment and selection process. The human resource practitioners with higher administrative expert role cognition can predict that their future job performance will be better than those who with lower intention. The construction of an excellent 
management system can produce positive benefits for organizational performance. From the empirical results, we see that the level of administrative expert role of HR practitioners has a significant positive impact on the human resource management system construction.

\section{Mediating Effect Test Between the Professional Ability and Management System Construction}

Empirical analysis showed that the administrative expert role does exist a partial mediating effect between professional ability and human resource system construction. This means that the level of administrative expert role cognition will affect human resource system formulation. Even for the low professional ability group, with higher administrative expert role cognition, the degree of influence on the system construction is higher. Therefore, how to increase the administrative expert role cognition degree will be the critical point. In practices application, department manager could set up the specific goal and measurable performance evaluation standards that can effectively raise up individual internal satisfaction and positive behavior intention. It meant that the higher degree of role cognition, the higher internal driving force for the completion of the work.

This research has some limitations. Study takes administrative expert role as the only mediating variable to explore the relationship between professional ability and human resource system formulation; other behavioral motivation variables should be considered in the future. By the way, human resource business partner still have the other three roles: strategic partner, change agent, employee champion. The future research may involve them into the framework then make a deeply discussion. Yet, this research provides a robust framework to study relationships among human resource practitioner professional abilities, administrative expert role, and the degree of human resource management system construction.

\section{REFERENCES}

Baron, R.M., \& Kenny, D.A. (1986). The moderator-mediator variable distinction in social psychological research: Conceptual, strategic, statistical considerations. Journal of Personality and Social Psychology, 51, 1173-1182.

Chen, Y. (2007). The Impact of Human Resource Role Task, Professional Competency, Achievement Motivation on Professional Commitment and Job Performance. Master Degree Dissertation, National Central University, Taiwan.

Deshpande S.P., \& Golhar, D.Y. (1994). HRM Practices in large and small manufacturing firms: A Comparative Study. Journal of Small Business Management, 32(2), 49-56.

George, D., \& Mallery, P. (2016). IBM SPSS statistics 23 step by step: A simple guide and reference. New York: Routledge.

Hall, D., \& Goodale, J. (1986). Human Resource Management. IL: Scott, Foresman and Company.

Hsu, S.W., Chen, S.Y., Chang, H.Y., \& Chen, Y.L. (2014). A Study of Organizational Innovations, Employee's Job Satisfaction and Service Quality in The International Tourist Hotels - Human Resource Management System as a Moderator. Commerce \& Management Quarterly, 15(4), 545-575.

Huselid, M.A., Jackson, S.E., \& Schuler, R.S. (1997). Technical and Strategic Human Resource Management Effectiveness as Determinants of Firm Performance. Academy of Management Journal, 40(1), 171-188.

Jamali, N., \& Sagirani, T. (2021). Quality assurance testing to improve the quality of human resource management system. Journal of Physics: Conference Series, 1918(4), 042139. https://doi.org/10.1088/1742-6596/1918/4/042139

Lemmergaard, J. (2009). From administrative expert to strategic partner. Employee Relations, 31, 182196.

Lievens, F., Decaesteker, C., Coetsier, P., \& Geirnaert, J.(2001). Organizational attractiveness for prospective applical ts: A person-organization fit perspective: An International Review. Applied Psychology, 50(1), 30-51. 
Lin, C.C., Li, X.F., \& Lam, W.L. (2019). Development or maintenance? Dual-oriented human resource system, employee achievement motivation, and work well-being. Human Resource Management. https://doi.org/10.1002/hrm.21997

Lin, C.C., Li, X.F., \& Lam, W.L. (2019). When and How Different Types of HR Practices Promote Work Well-being More Effectively: A Contingency Approach and Person-Organizational Fit Perspective. Academy of Management Proceedings, 1 . Retrieved from https://journals.aom.org/doi/10.5465/AMBPP.2019.20

Liu, J.Y., \& Shi, K. (2005). The Influence of Human Resource Management Practices on Organizational Commitment. Journal of Ergonomic, 11(4), 21-24.

Nunnally, J. (1978). Psychometric Theory (2nd ed). New York: McGraw-Hill.

Peng, K. (2012). The SMEs problems and solution in Henan Province. Master Degree Dissertation, Henan University.

Pural, P., \& Shabana, M. (2019). Core Functions of Human Resource Management and its Effectiveness on Organization: A Study. International Journal of Research in Economics and Social Sciences, 9(5), 257-266.

Ruona, W.E.A., \& Gibson, S.K. (2004). The making of twenty-first-century HR: An analysis of the convergence of HRM, HRD, and OD. Human Resource Management, 43(1), 49-66.

Schuler, R.S., \& MacMillan, I. (1984). Gaining competitive advantage through human resource practices. Human Resource Management, 23, 241-256.

Shun, H.Y. (2018). HR: Functional Administration to Business Partner. ShangHai: Ge Zhi Press.

Sun, M.Z. (2019). Application Status and Problems of HRBP Mode in China. Advances in Economics, Business and Management Research, 109, 653-656. Retrieved from http://creativecommons.org/licenses/by-nc/4.0/

Suzanne, R., Laszlo, S., \& Zsuzsanna, V.(2010). HRM in the Hungarian SME Sector. Employee Relations, 32(3), 262-280.

Tabachnick, B.G., \& Fidell, LS. (2007). Using multivariate statistics. Needham Height, MA: Allyn \& Bacon.

Ulrich, D. (1997). Human Resource Champions: The Next Agenda for Adding Value and Delivering Results. Harvard Business School Press.

Ulrich, D., \& Brockbank, W. (2005). The HR value proposition. Boston, MA: Harvard Business School Press.

Ulrich, D., Brockbank, W., Yeung, A.K. \& Lake, D.G. (1995). Human resource Competencies: An Empirical Assessment. Human Resource Management, 34(4), 473-495.

Wang, L. (2011). The solutions discussion on SMEs Human Resource Management. China Trade, 10, $84-91$.

Ward, U. (2015). The Future HR Roles of Shared Service Centres. IBA Bachelor Thesis Conference $5^{\text {th }}$. Enschede, The Netherlands.

Wigfield, A., \& Eccles, J.S.(2000). Expectancy-value theory of achievement motivation. Contemporary Educational Psychology, 25, 68-81.

Wright, P.M., Gardner, T.M., \& Moynihan, L.M.(2002). The Impact of Human Resource Practices on Business-Unit Operating and Financial Performance. Paper presented at the University of Bath conference on HR and Firm Performance.

Yu, J., Yu, J.J., Jiang, J.Q., Liao, P.W., \& Xu, L.Q. (2012). Research on the Integration and Transformation of Human Resource Department in Different Subsidiaries-A Case Study of a Financial Holding Group. Journal of Chinese Management Review, 15(2), 1-21.

Yusliza, M.Y. (2012). The Path from an Administrative Expert to a Strategic Partner Role: A Literature Review. Interdisciplinary Journal of Contemporary Research in Business, 3(9), 141-154.

Zhou, Y.Q. (2008). Human Resource Management: Navigation View of Cross Era (3rd Edition). QuanHua Press, Taipei. 